\title{
Nötrofil Lenfosit Oranı ve Monosit Lenfosit Oranı Çocukluk Çağı Tuberkülozu Tanısında Kullanılabilir mi?
}

\section{Can Neutrophil to Lymphocyte Ratio and Monocyte to Lymphocyte Ratio Be Used in the Diagnosis of Childhood Tuberculosis?}

\author{
${ }^{1}$ Şefika Elmas BOZDEMIR, ${ }^{2}$ Hümeyra ASLANER
}

${ }^{1}$ Department of Pediatric Infectious Diseases, Bursa City Training and Research Hospital, Bursa, Turkey

${ }^{2}$ Department of Family Practice, Kayseri City Training and Research Hospital, Kayseri, Turkey

Şefika Elmas Bozdemir: https://orcid.org/0000-0003-1058-0320

Hümeyra Aslaner: https://orcid.org/0000-0002-3710-3893

\begin{abstract}
ÖZ
Amaç: Nötrofil-lenfosit oran1 (NLO) ve monosit-lenfosit oranı (MLO) birçok hastalıkta bakteriyemi, hastalık aktivitesi, nüks oranı, sürveyans ve prognozu değerlendirmek için kullanılan yararlı inflamasyon biyobelirteçleridir. Bu çalışmada, enflamasyon belirteçleri olarak kullanılıp kullanılamayacaklarını göstermek için tüberkülozlu 92 çocuğun NLO ve MLO'sunu 45 sağlıklı çocukla karşılaştırarak değerlendirdik. Calıșmamızın amacı, çocukluk çağı TB tanısında NLO ve MLO'nun tanısal değerini göstermektir. Materyal ve Metot: $B u$ retrospektif çalıșmada, 92 tüberkülozlu çocuğun hastane kayitları gözden geçirildi. Hastaların NLO ve MLO değerleri 45 sağliklı çocuktan oluşan kontrol grubu ile karşılaştırıldı.

Bulgular: NLO ve MLO değerleri arasında tüberküloz hastaları ve kontrol grupları arasinda anlamlı fark bulundu ( $\mathrm{p}<0.001)$. Tüberküloz hastalarını kontrollerden ayırmak için NLO $>1.41$ kesme değeri optimaldi (duyarlılık \%75, özgüllük $\% 82,2$, pozitif öngörü değeri $\% 89,6$, negatif öngörü değeri \%61,7). MLO $>0.22$ kesme değeri, tüberküloz hastalarını kontrollerden ayırmak için optimaldi (duyarlılık \%50, özgüllük \%91,1, pozitif öngörü değeri \% 93,3 , negatif öngörü değeri \%53,2).

Sonuç: NLO ve MLO'nun her ikisi de çocukluk çaği tüberkülozunda inflamasyon belirteci olarak kullanılabilir. Daha net bir karar vermek için ileriye dönük ve daha kapsamlı çalışmalara ihtiyaç vardır.

Anahtar Kelimeler: İnflamasyon, lenfosit, nötrofil, tüberküloz
\end{abstract}

\begin{abstract}
Objective: Neutrophil-lymphocyte ratio (NLR) and monocyte-lymphocyte ratio (MLR) are useful biomarkers of inflammation used to evaluate bacteremia, disease activity, recurrence rate, surveillance and prognosis in many diseases. In this study, we evaluated NLR and MLR of 92 children with tuberculosis versus 45 healthy children to show whether they can be used as inflammation markers. Aim of this study was to evaluate the diagnostic valure of NLR and MLR in childhood tuberculosis.
\end{abstract}

Materials and Methods: In this retrospective study, hospital records of 92 children with tuberculosis were reviewed. The NLR and MLR values of the patients were compared with the control group of 45 healthy children.

Results: A significant difference was found between NLO and MLO values between tuberculosis and control groups $(p<0.001)$. A cut off value of NLR $>1.41$ was optimal for discriminating patients with tuberculosis from controls (sensitivity $75 \%$, specifity $82.2 \%$, positive predictive value $89.6 \%$, negative predictive value $61.7 \%$ ). A cut off value of MLR $>0.22$ was optimal for discriminating patients with tuberculosis from controls (sensitivity $50 \%$, specifity $91.1 \%$, positive predictive value $93.3 \%$, negative predictive value $53.2 \%$ ).

Conclusion: NLR and MLR can both be used as inflammation biomarkers in the diagnosis of childhood tuberculosis. Prospective and more comprehensive studies are needed to make a clearer decision.

Keywords: Inflammation, lymphocyte, neutrophil, tuberculosis
Sorumlu Yazar / Corresponding Author:

Hümeyra Aslaner

Kayseri City Training and Research Hospital, Şeker Mah., Mu-

hsin Yazıcıoğlu Cad. No:77 Kocasinan / Kayseri/Turkey

Tel: +905066456944 / +903523157700

Fax: +903523157986

E-mail: drhumeyra@hotmail.com
Yayın Bilgisi / Article Info:

Gönderi Tarihi/ Received: 25/05/202

Kabul Tarihi/ Accepted: 02/11/2021

Online Yayın Tarihi/ Published: 01/12/2021

Atıf / Cited: Bozdemir SSE and Aslaner H. Have Can Neutrophil to Lymphocyte Ratio and Monocyte to Lymphocyte Ratio Be Used In The Diagnosis of Childhood Tuberculosis?. Online Türk Sağllk Bilimleri Dergisi 2021;6(4):521-527. doi:10.26453/otjhs.903130 


\section{INTRODUCTION}

Globally, the best estimate is that 10 million people (range, 9.0-11.1 million) developed tuberculosis disease in 2017: 5.8 million men, 3.2 million women and 1.0 million children. ${ }^{1}$ On May 23, 2018, the International Union Against Tuberculosis and Lung Disease (the Union) issued a report called "Silent Epidemic: A Call to Action Against Child Tuberculosis". Launched at the World Health Assembly, the report noted that an estimated 239000 children aged younger than 15 years died from tuberculosis in $2015,90 \%$ of whom were untreated. ${ }^{2}$ The authors drew attention to the continuing medical neglect of child tuberculosis, resulting in millions of avoidable deaths. Several factors lie behind this neglect. First of all pediatric tuberculosis is difficult to discriminate from pneumonia, second children have usually paucibacillary disease and cannot generate sputum easily, third many child care facilities are illequipped to diagnose and treat childhood tuberculosis disease. However, the crucial point is that although children contract tuberculosis disease from an adult family member, the contacts in pediatric age are not surveyed and treated properly. In 2016, only $13 \%$ of children eligibile for INH prophylaxis treatment, could received it. ${ }^{1,2}$ The point that children do not generate much sputum and have paucibacillary disease that making the diagnosis difficult, lead the authors suggest investigating new diagnostics like bodily secretions other than sputum. ${ }^{2}$ From this perspective, we searched for a new, cheap and easily accessible marker contributing to the diagnosis of childhood tuberculosis. We decided to evaluate the inflammation markers of neutrophil to lymphocyte ratio (NLR), and monocyte to lymphocyte ratio (MLR) in the tuberculosis patients by comparing with healthy children. NLR is long time is used as a marker of inflammation in several rheumatologic, cancer and/or infectious diseases. ${ }^{3-7}$ NLR is found to be useful in adult tuberculosis disease for differential diagnosis from sarcoidosis and community acquired pneumonia in some studies. ${ }^{8,9}$ Lymphocytopenia has also been described as a diagnostic marker of bacterial infection. ${ }^{8,10}$ Also, myeloid-specific cells have been known to serve as host cells for Mycobacterium tuberculosis growth and lymphoid cells are thought to be the major effector cells in TB immunity. Given the central role of monocytes and lymphocytes in the induction of immune responses, their levels (MLR) in peripheral blood might be expected to reflect the state of an individual's immunity to tuberculosis disease. ${ }^{11}$ The well known inflammation markers erythrocyte sedimentation rate (ESR) and C-reactive protein (CRP) were compared between the tuberculosis patients and healthy control group.

\section{MATERIALS AND METHODS}

Ethical approval was obtained for this study from the Non-Interventional Clinical Ethics Committee of University of Health Sciences, Bursa Yuksek Specialization Training and Research Hospital (Date: 02/01/2019, decision no: 2011-KAEK-25 2019/0126).

This retrospective study was performed in University of Health Sciences, Bursa Yuksek Ihtisas Training and Research Hospital and Dortcelik Children's Hospital between January 2016 and January 2019. The medical records of patients who were diagnosed and treated for tuberculosis disease were evaluated. A total of 92 children with tuberculosis disease; tuberculosis group and 45 healthy children; control group were enrolled in the study.

The diagnosis of pulmonary tuberculosis disease was established according to the first 3 diagnostic categories of NIH criteria. ${ }^{12}$ The first category included confirmed tuberculosis cases with positive smear of sputum or early morning gastric aspirate and/or positive culture for Mycobacterium tuberculosis. The second category included highly probable cases having clinical symptoms and radiological signs of tuberculosis disease with an active or recently treated family member with tuberculosis disease. The third category included possible cases with positive Tuberculin skin test (TST) or Interferon Gamma Releasing Assays and not responding to standart pneumonia treatment, with/or without an active or recently treated family member with tuberculosis disease. All the children in the third group fully recovered with antituberculosis treatment. Diagnosis of all extrapulmonary tuberculosis cases depended on pathological confirmation. Healthy children were selected through children who applied to hospital for routine check-up, or vaccination status screening or for preoperative evaluation of minor elective surgery (for example: hernia repair). Children with any sign of infection or systemic illness were excluded from the control group.

Hematological parameters including white blood cell (WBC) count, hemoglobin (Hb), neutrophil count, lymphocyte count, platelet count (PLT), monocyte count and mean platelet volume (MPV) were recorded for all groups. Neutrophil to lymphocyte ratio (NLR), monocyte to lymphocyte ratio (MLR) and platelet to lymphocyte ratio (PLR) were calculated as the ratio of neutrophils to lymphocytes, monocytes to lymphocytes and platelets to lymphocytes, respectively. CRP and ESR of all tuberculosis patients and control cases whose existing were recorded. Comparison between the two groups were performed with regards to WBC, neutrophil count, lymphocyte count, monocyte count, platelet count, MPV, NLR and PLR. White blood cell, Hb, neutrophil 
count, lymphocyte count, PLT, MPV, NLR, MLR and PLR values. CRP and ESR were also compared between the tuberculosis and control groups.

All kinds of blood cell counts were made in Sysmex $\mathrm{XN}-350$ and C-reactive protein measures were held on BN Prospec (Dade Behring, Siemens) Nephelometer.

Statistical Analysis: The normality of data distribution was determined using the Kolmogorov-Smirnov test. Normally distributed numerical variables were expressed in mean plus/minus standard deviation. Normally distributed numerical variables were compared using the Student's t-test or One-way ANOVA test. Tukey test was used for Post Hoc Tests. Data corresponding to an abnormal distribution were expressed in median (minimum-maximum). Abnormally distrubuted numerical data were compared using the non-parametric Mann-Whitney U-test or Kruskal-Wallis test. The Chi-square test was used to compare categorical variables between the groups. Correlation between NLR and other parameters was analyzed using Spearman's rank correlation test. ROC curve analysis was performed to identify the most useful cut-off levels for NLR, MLR, CRP to identify the greatest sum of sensitivity and specificity for distinguishing tuberculosis disease from healthy controls. The ability of NLR, MLR and CRP to distinguish pulmonary tuberculosis from healthy controls was compared using the area under the curve (AUC). P-values of less than 0.05 were considered statistically significant. SPSS version 22.0 (IBM Corp., Armonk, NY, USA) was used for analyses.

\section{RESULTS}

Mean age in the tuberculosis group was 116.23 months and median age was 123.5 (6-125) months and $54.4 \%(\mathrm{n}=50)$ were male. Mean age in the control group was 116.23 months and median age was 92 (16-194) months and 62.2\% $(\mathrm{n}=28)$ were male. There were no statistically significant difference among the median ages $(\mathrm{p}=0.258)$ and gender distribution ( $\mathrm{p}=0.463$ ) between the groups. Of the patients; $62(67.4 \%)$ were pulmonary tuberculosis, 13 (14.2\%) were tuberculous peripheral lymphadenitis, $8(8.7 \%)$ were abdominal tuberculosis, 4 (4.4\%) were renal tuberculosis, $3(3.2 \%)$ were tuberculous meningitis, $1(1.1 \%)$ was tuberculous pericarditis, 1 $(1.1 \%)$ was disseminated BCG'itis. Most common symptoms in tuberculosis group at admission were persistent cough $(75 \%)$, anorexia $(69.6 \%)$, night sweats $(67.4 \%)$, weakness $(63.1 \%)$, peripheral lymphadenitis $(25 \%)$ abdominal pain $(15.2 \%)$ and hemoptizis $(15.2 \%)$. TST of $\geq 15 \mathrm{~mm}$ was found in $65.2 \%(60 / 92)$ (BCG vaccination is a part of routine childhood vaccination program applied at age 2 months in Turkey), $\geq 10 \mathrm{~mm}$ was found in $68.5 \%$
(63/92) while the anergy rate was $21.8 \%(21 / 92)$ in the tuberculosis group. Of the patients 31 (33.7\%) had microbiological diagnosis (Mycobacterium tuberculosis was positive and/or grew either in sputum or early morning gastric aspirate (GA) or another body fluid (pleural fluid), 24 (26.1\%) patients had hystopathological diagnosis, 37 (40.2\%) patients had clinical and radiological diagnosis (Table 1).

Median WBC was $10500 / \mathrm{mm}^{3}(4100-37410)$, hemoglobin was $11,43 \pm 1,99 \mathrm{mg} / \mathrm{dL}$, neutrophil count was $6170 / \mathrm{mm}^{3}(2220-22520)$, lymphocyte count was $2630 / \mathrm{mm}^{3}$ (660-11220) monocyte count $730 / \mathrm{mm}^{3}$ (310-2790), NLR was 2,02 (0,43-30,43), MLR was $0,29(0,10-1,92)$, platelet count $347.500 / \mathrm{mm}^{3}$ (181.000-888.000) and MPV was $8,47 \pm 1,07$ in the tuberculosis group. Median WBC was $6450 / \mathrm{mm}^{3}$ (4000-8980), hemoglobin was $13,65 \pm 1,32 \mathrm{mg} / \mathrm{dL}$, neutrophil count was $3190 / \mathrm{mm}^{3}(1600-5090)$, lymphocyte count was $3040 / \mathrm{mm}^{3}$ (1870-4100), monocyte count $410 / \mathrm{mm}^{3}(260-590)$, NLR was $0,97(0,63$ 2,08), MLR was $0,14(0,09-0,28)$, platelet count $315.000 / \mathrm{mm}^{3}(181.000-500.000)$ and MPV was 9,14 $\pm 0,66$ in the healthy control group. There was statistically significant difference among WBC, hemoglobin, neutrophil count, lymphocyte count, monocyte count, MPV, NLR, MLR and PLR values between the groups $(p<0.05)$. There was no statistically significant difference among platelet count between the groups ( $\mathrm{p}>0.05$ ) (Table 2 ).

The ESR was studied in 53 (57.6\%) tuberculosis patients and in $13(28.8 \%)$ controls. The median values were $34 \mathrm{~mm} / \mathrm{h}(5-140 \mathrm{~mm} / \mathrm{h})$ and $2 \mathrm{~mm} / \mathrm{h}(2$ $10 \mathrm{~mm} / \mathrm{h})$, respectively. There was significant difference among ESR values between the tuberculosis and control group $(\mathrm{p}<0.001)$. CRP was studied in 81 $(88 \%)$ tuberculosis patients and in $33(73.3 \%)$ control group. The median CRP values were $41 \mathrm{mg} / \mathrm{L}$ (3.23-290 mg/L) and $3.28 \mathrm{mg} / \mathrm{L}(3.17-3.45 \mathrm{mg} / \mathrm{L})$, respectively. There was significant difference among CRP values between the tuberculosis and control group $(\mathrm{p}<0.001)$ (Table 2$)$.

The strongest correlation was noted between NLR and MLR $(\mathrm{r}=0.838, \mathrm{P}<0.001)$. Positive correlation was also detected between NLR and WBC $(\mathrm{r}=0.804$, $\mathrm{P}<0.001)$, NLR and PLR $(\mathrm{r}=0.707, \mathrm{P}<0.001)$ as well as NLR and CRP $(r=0.519, \mathrm{P}<0.001)$. A negative correlation was identified between NLR and lymphocyte count $(\mathrm{r}=-0.704, \mathrm{P}<0.001)$.

A NLR $>1.4$ was identified as the optimal cut-off value for dis-criminating patients with pulmonary TB from controls, yielding 75\% sensitivity, $82.2 \%$ specificity, $89.6 \%$ posi-tive predictive value, and $61.7 \%$ negative predictive value. A MLR $>0.22$ was identified as the optimal cut-off value for discriminating patients with pulmonary tuberculosis from controls, yielding $60.9 \%$ sensitivity, $91.1 \%$ 
specificity, 93.3\% posi-tive predictive value, and $53.2 \%$ negative predictive value. A CRP $>4 \mathrm{mg} / \mathrm{L}$ was identified as the optimal cut-off value for discriminating patients with pulmonary tuberculosis

Table 1. Demographic, clinical, laboratory features of tuberculosis patients.

\begin{tabular}{|c|c|}
\hline Demographic and clinical features & Mean \pm SD or median (min-max) \\
\hline $\begin{array}{l}\text { Median age } \\
\text { Gender }\end{array}$ & $\begin{array}{l}113.1 \pm 57.1 \text { or } 116(6-215) \\
\text { Male }=50,54.4 \%, \text { Female }=42 ; 45.6 \%\end{array}$ \\
\hline Tuberculosis subgroups & Number, ratio $(\mathrm{N}=92 ; \mathrm{n} ; \mathrm{n} / \mathrm{N}=\%)$ \\
\hline $\begin{array}{l}\text { Pulmonary tuberculosis } \\
\text { Tuberculous peripheral lymphadenitis } \\
\text { Abdominal tuberculosis } \\
\text { Renal tuberculosis } \\
\text { Tuberculous meningitis } \\
\text { Tuberculous pericarditis } \\
\text { Disseminated BCG itis }\end{array}$ & $\begin{array}{l}62 ; 67.4 \% \\
13 ; 14.2 \% \\
8 ; 8.7 \% \\
4 ; 4.4 \% \\
3 ; 3.2 \% \\
1 ; 1.1 \% \\
1 ; 1.1 \%\end{array}$ \\
\hline Symptoms and clinical signs & Number, ratio $(\mathrm{N}=92 ; \mathrm{n} ; \mathrm{n} / \mathrm{N}=\%)$ \\
\hline $\begin{array}{l}\text { Persistent cough } \\
\text { Anorexia } \\
\text { Night Sweats } \\
\text { Weakness } \\
\text { Peripheral lymphadenitis } \\
\text { Abdominal pain } \\
\text { Hemoptizis }\end{array}$ & $\begin{array}{l}69 ; 75 \% \\
64 ; 69.6 \% \\
62 ; 67.4 \% \\
58 ; 63.1 \% \\
23 ; 25 \% \\
14 ; 15.2 \% \\
14 ; 15.2 \%\end{array}$ \\
\hline TST results & Number; ratio $(\mathrm{N}=60 ; n ; n / N=\%)$ \\
\hline $\begin{array}{l}\geq 15 \mathrm{~mm} \\
\geq 10 \mathrm{~mm} \\
5-10 \mathrm{~mm} \\
0-5 \mathrm{~mm} \\
\text { Anergy }\end{array}$ & $\begin{array}{l}60 ; 65.2 \% \\
63 ; 68,5 \% \\
4 ; 4.4 \% \\
4 ; 4.4 \% \\
21 ; 21,8 \%\end{array}$ \\
\hline Diagnostic evidence & Number; ratio $(\mathrm{N}=60 ; n ; n / N=\%)$ \\
\hline $\begin{array}{l}\text { Microbiological confirmation } \\
\text { Hystopathological confirmation } \\
\text { Clinically and radiologically diagnosed }\end{array}$ & $\begin{array}{l}31 ; 33.7 \% \\
24 ; 26.1 \% \\
37 ; 40.2 \%\end{array}$ \\
\hline Erytrocyte sedimentation rate & $34 \mathrm{~mm} / \mathrm{h}(5-140)$ \\
\hline C-reactive protein & $41 \mathrm{mg} / \mathrm{dL}(3.23-290)$ \\
\hline
\end{tabular}

Table 2. Comparison of the laboratory findings of the tuberculosis and control group.

\begin{tabular}{|l|l|l|l|}
\hline Parameter & Tuberculosis group & $\begin{array}{l}\text { Control group } \\
\text { Mean } \pm \text { SD or median (min- } \\
\text { max) }\end{array}$ & p \\
\hline WBC $\left(/ \mathrm{mm}^{3}\right)$ & $10500(4100-37410)$ & $6450(4000-8980)$ & $<\mathbf{0 . 0 0 1}$ \\
\hline Neutrophil count $\left(/ \mathrm{mm}^{3}\right)$ & $6170(2220-22520)$ & $3190(1600-5090)$, & $<\mathbf{0 . 0 0 1}$ \\
\hline Lymphocyte count $\left(/ \mathrm{mm}^{3}\right)$ & $2630(660-11220)$ & $3040(1870-4100$ & $\mathbf{0 . 0 1 3}$ \\
\hline Monocyte count $\left(/ \mathrm{mm}^{3}\right.$ & $730(310-2790)$ & $410(260-590)$ & $<\mathbf{0 . 0 0 1}$ \\
\hline NLR & $2,02(0,43-30,43)$ & $0.97(0.63-2.08)$ & $<\mathbf{0 . 0 0 1}$ \\
\hline MLR & $0,29(0,10-1,92)$ & $0.29(0.10-1.92)$ & $<\mathbf{0 . 0 0 1}$ \\
\hline Hemoglobin $\left(\mathrm{g} / \mathrm{dL}^{3}\right)$ & $12.5(6.9-15.9)$ & $13.2(10.9-16.0)$ & $<\mathbf{0 . 0 0 1}$ \\
\hline Platelet count $\left(/ \mathrm{mm}^{3}\right)$ & 347.500 & 315.000 & $(181.000-500.000)$ \\
\hline MPV $(\mathrm{fL})$ & $(181.000-888.000)$ & $9.14 \pm 0.66$ & 0.059 \\
\hline ESR $(\mathrm{mm} / \mathrm{h})$ & $8.47 \pm 1.07$ & $2(2-10)$ & $\mathbf{0 . 0 0 8}$ \\
\hline CRP $(\mathrm{mg} / \mathrm{L})$ & $34(5-140)$ & $3.28(3.17-3.45)$ & $<\mathbf{0 . 0 0 1}$ \\
\hline
\end{tabular}

WBC: White blood cell; NLR: Neutrophil-lymphocyte ratio; MLR: Monocyte-lymphocyte ratio; MPV: Mean platelet volume; ESR: Erytrocyte sedimentation rate; CRP: c-Reactive protein.

Table 3. Diagnostic validity of NLR, MLR, CRP and ESR values in tuberculosis diagnosis.

\begin{tabular}{|l|l|l|l|l|l|}
\hline & Sensitivity & Specifity & PPV & NPV & Accuracy \\
\hline NLR $>1.4$ & 0.75 & 82.2 & 89.6 & 61.7 & 81.3 \\
\hline MLR $>0.22$ & 60.9 & 91.1 & 93.3 & 53.2 & 81.5 \\
\hline $\mathrm{CRP}>4 \mathrm{mg} / \mathrm{L}$ & 72.8 & 100 & 100 & 60 & 84.3 \\
\hline $\mathrm{ESR}>11 \mathrm{~mm} / \mathrm{h}$ & 81.1 & 100 & 100 & 56.5 & 96.0 \\
\hline
\end{tabular}

PPV: positive predictive value, NPV: negative predictive value, NLR: neutrophil-lymphocyte ratio, MLR: monocyte-lymphocyte ratio, CRP: c-reactive protein, ESR: erytrocyte sedimentation rate 
from controls, yielding $72.8 \%$ sensitivity, $100 \%$ specificity, $100 \%$ posi-tive predictive value, and $60 \%$ negative predictive value. An ESR $>11 \mathrm{~mm} / \mathrm{h}$ was identified as the optimal cut-off value for discriminating patients with pulmonary tuberculosis from controls, yielding $81.1 \%$ sensitivity, $100 \%$ specificity, $100 \%$ posi-tive predictive value, and $56.5 \%$ negative predictive value (Table 3 ).
The NLR AUC (AUC, 0.813; 95\% confidence interval [CI], 0.73-0.87; $<0.001$ ) and MLR AUC (AUC, $0.815 ; 95 \%$ confidence interval [CI], 0.74-0.87; $\mathrm{p}<0.001)$ were comparable to that of CRP AUC (AUC, 0.843; 95\% CI, 0.76-0.90; P <0.001) (Figure 1). The ESR AUC (AUC, 0.96; 95\% confidence interval [CI], 0.88-0.99; $\mathrm{p}<0.001)$ was the highest of all inflammatory parameters.

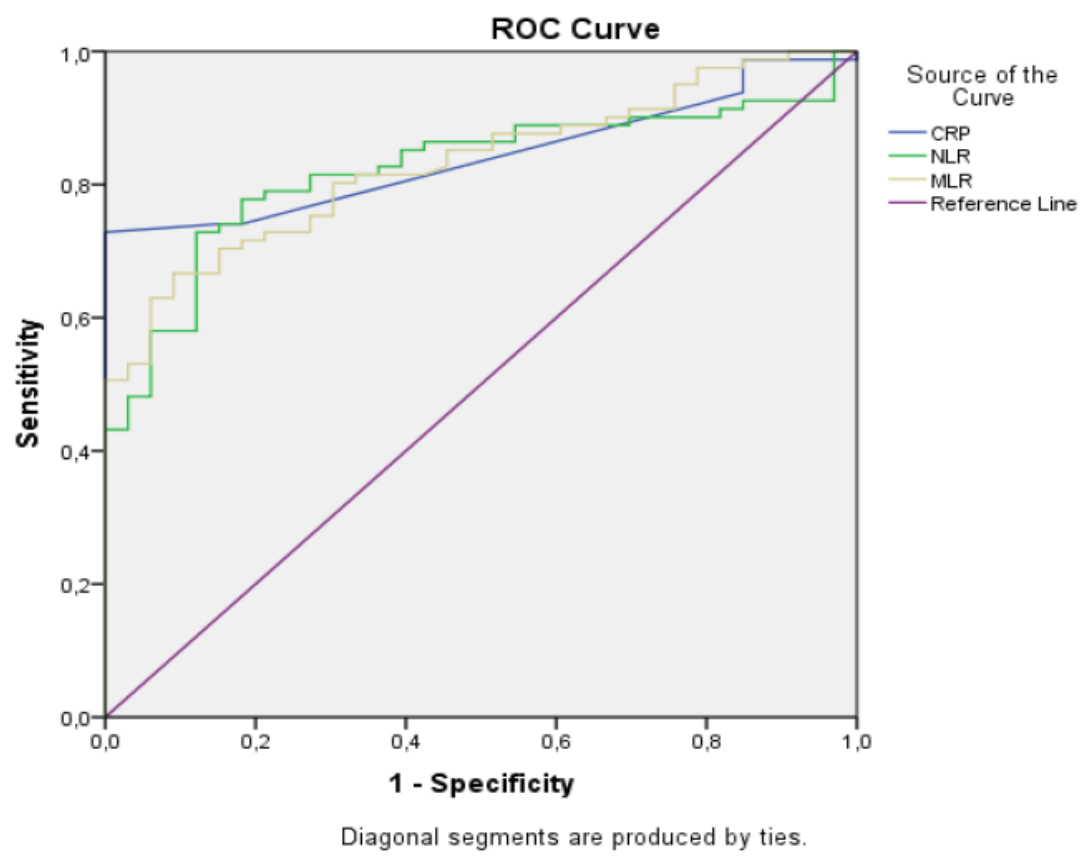

Figure 1. ROC curves of C-reactive protein (CRP) and neutrophil-lym-phocyte count ratio (NLR) and monocyte-lymphocyte count ratio (MLR) in tuberculosis diagnosis. The area under the curve for NLR (AUC, $0.813 ; 95 \%$ confidence interval [CI], 0.73-0.87) and MLR (AUC, 0.815; 95\% confidence interval [CI], 0.74-0.87) was comparable to that for CRP (AUC, AUC, $0.843 ; 95 \%$ CI, 0.76-0.90) $(\mathrm{p}<0.001)$.

\section{DISCUSSION AND CONCLUSION}

Children with tuberculosis disease are usually diagnosed after an elderly family member having active tuberculosis or pretreated tuberculosis in the family. In this study $73,9 \%$ (68/92) of tuberculosis patients had a family member with either current or formerly tuberculosis disease history. 7.6\% (7/92) patients without any family history were followed with cerebral palcy (CP) and epilepcy (5/7), severe cystic fibrosis $(2 / 7)$ with frequent intensive care unit admissions from birth to diagnosis. $3.2 \%(3 / 5)$ of these $\mathrm{CP}$ and epileptic children were Syrian immigrants. More than half of these children 55.4\% (51/92) were referred to our pediatric infection clinic with symptoms and/or evidence of tuberculosis disease based on the contact history. Of the study group, $75 \%$ (69/92) had persistent cough (cough $\geq 3$ weeks), $69.5 \%(64 / 92)$ had anorexia, 67.3\% (62/92) had night sweats, $15.2 \%(14 / 92)$ had hemoptizis on admission remarking tuberculosis disease.
Hematological parameters are being used for a long time to exhibit their role in the systemic inflammatory response to infection. ${ }^{13,14}$ In a study by Abakay et al. NLR was reported to be significantly higher in patients with advanced pulmonary TB as opposed to patients with mild to moderate pulmonary tuberculosis. ${ }^{15}$ In the study by Yoon et al. ${ }^{8}$ They stated that a NLR $<7$ could be used for the discrimination of tuberculosis and community acquired pneumonia (CAP) in the adults. They found that a NLR $<7$ was more sensitive than a $\mathrm{CRP}<7 \mathrm{mg} / \mathrm{dL}$ for discriminating tuberculosis from CAP. Leem et al. evaluated the NLR of tuberculosis patients on admission, at 2 months and after treatment and concluded that NLR can be a useful marker to evaluate response to antituberculosis treatment. ${ }^{16}$ In this study, we found that a NLR $>1.4$ was associated with $75 \%$ sensitivity and $82.2 \%$ specificity in diagnosing tuberculosis disease in children. NLR was also found more sensitive than CRP in the diagnosis of tuberculosis disease in this 
study group.

Myeloid-specific cells have been known to serve as host cells for Mycobacterium tuberculosis growth and lymphoid cells are thought to be the major effector cells in tuberculosis immunity. ${ }^{6}$ Wang $\mathrm{J}$ et al. found that a MLR $<9 \%$ or $>25 \%$ was predictive of active tuberculosis in adult patients. ${ }^{17}$ Rakotosamimanana et al. found that MLR (adjusted hazard ratio aHR $>4.97,95 \%$ CI 1.3-18.99; $p=0.03$ ) was significantly associated with risk of developing active tuberculosis disease in HIV-negative household contacts $(n=296)$ of pulmonary tuberculosis patients. ${ }^{18}$ In the study a cut-off point $7.5 \%$ monocytes in total peripheral blood mononuclear cells gave the best separation (HR 8.46, 95\% CI 1.73-41.22; p<0.01), and was associated with a sensitivity and specificity of $75 \%$. In the study by Choudhary et al. MLR $>0.378$ identified HIV+ children with confirmed tuberculosis with $77 \%$ sensitivity, $78 \%$ specificity, $24 \%$ positive predictive value, and $97 \%$ negative predictive value. ${ }^{19}$ Jain et al. reported that a higher mean (SD) MLR [0.38 (0.30) vs. 0.24 (0.02); $\mathrm{p}=0.037]$ was associated with microbiological confirmation in children with tuberculosis. ${ }^{20}$ In this study MLR $>0.22$ was associated with $60.9 \%$ sensitivity and $91.1 \%$ specifity diagnosing tuberculosis disease in children. We conclude these results are comparable to the results above.

The retrospective nature of this study is a limiting factor. Also, we included all tuberculosis patients in the study either with definite or probable (cases with radiological plus clinical evidence plus contact history) diagnosis with small group concern. Also, the study group consisted of small numbers of extrapulmonary tuberculosis patients which limited us to compare subgroups.

In conclusion, NLR and MLR can be used as useful biomarkers together in childhood tuberculosis diagnosis. Further prospective studies are needed to compare these results and make a final decision.

Ethics Committee Approval: The study was approved by the Ethics Committee of the University of Health Sciences, Bursa Yuksek Ihtisas Training and Research Hospital Noninvasive Researchs Ethics Committee (Date: 02/01/2019, decision no: 2011 KAEK-25 2019/01-26).

Conflict of Interest: No conflict of interest was declared by the authors.

Author Contributions: Concept - ŞEB; Supervision - ŞEB, HA; Materials - HA; Data Collection and/or Processing - ŞEB, HA; Analysis and/ or Interpretation - SEB, HA; Writing SSB, HA.

Peer-review: Externally peer-reviewed.

\section{REFERENCES}

1. World Health Organization. Global Tuberculosis
Report 2018. https://apps.who.int/iris/bitstream/ handle/10665/274453/9789241565646-eng.pdf? sequence $=1 \&$ isAllowed $=y$. Accessed 12 November 2018.

2. Burki T. Neglecting childhood tuberculosis "a human rights violation". Lancet Infect Dis. 2018;18(7):723. doi:10.1016/S1473-3099(18) 30365-7

3. Demir F, Karadeniz C, Özdemir R, et al. Usefulness of Neutrophil to Lymphocyte Ratio in Prediction of Coronary Artery Lesions in Patients with Kawasaki Disease. Balkan Med J. 2015;32 (4):371-376.

doi: $10.5152 /$ balkanmedj.2015.151108

4. Uygur F, Tanriverdi H, Aktop Z, et al. The neutrophil-to-lymphocyte ratio in patients with obstructive sleep apnoea syndrome and its relationship with cardiovascular disease. Heart Lung. 2016;45(2):121-125. doi:10.1016/ j.hrtlng.2016.01.002

5. Kucuk A, Erol MF, Senel S, et al. The role of neutrophil lymphocyte ratio to leverage the differential diagnosis of familial Mediterranean fever attack and acute appendicitis. Korean J Intern Med. 2016;31(2):386-391. doi:10.3904/ kjim.2015.039

6. Gokcen K, Dundar G, Gulbahar H, Gokce G, Gultekin EY. Can routine peripheral blood counts like neutrophil-to-lymphocyte ratio be beneficial in prediagnosis of testicular cancer and its stages? J Res Med Sci. 2018;23:64. doi:10.4103/ jrms.JRMS_1009_16

7. Bozdemir ȘE, Altıntop YA, Uytun S, Aslaner H, Torun YA. Diagnostic role of mean platelet volume and neutrophil to lymphocyte ratio in childhood brucellosis. Korean J Intern Med. 2017;32 (6):1075-1081. doi:10.3904/kjim.2016.092

8. Yoon NB, Son C, Um SJ. Role of the neutrophillymphocyte count ratio in the differential diagnosis between pulmonary tuberculosis and bacterial community-acquired pneumonia. Ann Lab Med. 2013;33(2):105-110.

doi:10.3343/ alm.2013.33.2.105

9. Iliaz S, Iliaz R, Ortakoylu G, Bahadir A, Bagci BA, Caglar E. Value of neutrophil/lymphocyte ratio in the differential diagnosis of sarcoidosis and tuberculosis. Ann Thorac Med. 2014;9 (4):232-235. doi:10.4103/1817-1737.140135

10. Wyllie DH, Bowler IC, Peto TE. Relation between lymphopenia and bacteraemia in UK adults with medical emergencies. J Clin Pathol. 2004;57(9):950-955. doi:10.1136/ jcp.2004.017335

11. Naranbhai V, Hill AV, Abdool Karim SS, et al. Ratio of monocytes to lymphocytes in peripheral blood identifies adults at risk of incident tuberculosis among HIV-infected adults initiating anti- 
retroviral therapy. J Infect Dis. 2014;209(4):500509. doi:10.1093/infdis/jit494

12. Beneri CA, Aaron L, Kim S, et al. Understanding NIH clinical case definitions for pediatric intrathoracic TB by applying them to a clinical trial. Int J Tuberc Lung Dis. 2016;20(1):93-100. doi:10.5588/ijtld.14.0848

13. Jilma B, Blann A, Pernerstorfer T, et al. Regulation of adhesion molecules during human endotoxemia. No acute effects of aspirin. Am J Respir Crit Care Med. 1999;159(3):857-863.

14. Kiran B, Cagatay T, Clark P, et al. Can immune parameters be used as predictors to distinguish between pulmonary multidrug-resistant and drug -sensitive tuberculosis? Arch Med Sci. 2010;6 (1):77-82. doi:10.5114/aoms.2010.13511

15. Abakay O, Abakay A, Sen HS, Tanrikulu AC. The relationship between inflammatory marker levels and pulmonary tuberculosis severity. Inflammation. 2015;38(2):691-696. doi:10.1007/ s10753-014-9978-y

16. Leem AY, Song JH, Lee EH, et al. Changes in cytokine responses to TB antigens ESAT-6, CFP -10 and TB 7.7 and inflammatory markers in peripheral blood during therapy. Sci Rep. 2018;8 (1):1159. doi:10.1038/s41598-018-19523-7

17. Wang J, Yin Y, Wang X, et al. Ratio of monocytes to lymphocytes in peripheral blood in patients diagnosed with active tuberculosis. Braz J Infect Dis. 2015;19(2):125-131. doi:10.1016/ j.bjid.2014.10.008

18. Rakotosamimanana N, Richard V, Raharimanga $\mathrm{V}$, et al. Biomarkers for risk of developing active tuberculosis in contacts of TB patients: a prospective cohort study. Eur Respir J. 2015;46 (4):1095-1103. doi:10.1183/13993003.002632015

19. Choudhary RK, Wall KM, Njuguna I, et al. Monocyte-to-Lymphocyte Ratio Is Associated With Tuberculosis Disease and Declines With Anti-TB Treatment in HIV-Infected Children. J Acquir Immune Defic Syndr. 2019;80(2):174-181. doi:10.1097/QAI.0000000000001893

20. Jain R, Mukherjee A, Singla M, et al. Predictors of Microbiologically Confirmed Intrathoracic Tuberculosis. Indian J Pediatr. 2017;84(11):843847. doi:10.1007/s12098-017-2467-1 